\title{
Party Youth Wing Membership in the Netherlands: The Role of Organization-
}

\section{Level Characteristics ${ }^{1}$}

Charlotte de Roon

Faculty Governance and Global Affairs, Leiden University

Schouwburgstraat 2, 2511 VA Den Haag, The Netherlands

E-mail: c.j.de.roon@fgga.leidenuniv.nl

Phone: +31 708009586

\begin{abstract}
Party youth wings are common all over the world. They are expected to play an important role in linking young people to political parties. However, empirical research on the performance of party youth wings is scarce and political youth participation is seen as problematic. To what extent have party youth wings actually succeeded in attracting members over the last decade? And how can variations in party youth wing membership levels be explained? In order to answer these questions, this article develops and tests organization-based explanations on a unique dataset that contains data for nine party youth wings and the corresponding mother parties in the Netherlands over a period from 2001 to 2016. It is found that youth wings are still a popular form of organizational linkage for parties. While the total party youth wing membership in the Netherlands is on the rise, large variations between party youth wings and their mother parties exist. Membership levels appear to be affected by the membership levels of the mother party. The older the party youth wing, the higher the membership levels. Other party-related characteristics, such as ideology and the age of the party youth wing, do not seem to play a role.
\end{abstract}

Keywords: party youth wings; membership; time-series cross-sectional data; the Netherlands

\footnotetext{
${ }^{1}$ This is a post-peer-review, pre-copyedit version of an article published in Acta Politica. The final authenticated version is available online at: https://doi.org/10.1057/s41269-019-00135-6
} 
"Youth should be able to develop the skills and motivation to be successfully engaged in political parties, and parties should be encouraged to create space for youth. Affirmative action measures such as youth and women's quotas and party youth wings can help move these processes forward” (United Nations Development Programme, 2013, p. 28).

\section{Introduction}

Today, an important challenge for political parties is to attract engaged young people. Most parties in Western democracies have not only been suffering from declining memberships for over several decades now (Van Biezen et al, 2012), their membership base has been increasingly ageing as well (Scarrow and Gezgor, 2010). In fact, a lack of generational replacement has been argued to explain the decline in party membership in European democracies (Whiteley, 2007). The interplay of these developments has led scholars to express concerns about the current and future functioning of our democracies. Parties play a central role in connecting society to the state, a function which cannot be fully fulfilled without the support and supply of young people.

Within this context, one relevant aspect has attracted little attention in the literature: party youth wings. These party sub-organizations are political organizations led by young people and open to membership of young people within a limited age range, in order for political parties to establish a connection with young people. The relatively low interest in party youth wings is surprising, as they are common in democracies worldwide and can fulfil several democratic functions. Party youth wings are found to be the dominating type of collateral organization in the organizational network of parties in Western democracies (Poguntke, 2006). Not only older parties have a youth wing; even new parties start party youth wings. In the Netherlands, for instance, two new party youth wings recently came on to the scene: the youth organizations of the newly established national-conservative party Forum for Democracy (FvD) and the pro-immigrant party DENK. Party youth wings are of interest to parties because they can fulfil various important 
functions, such as a linkage function (Poguntke, 2006; Poguntke, 2002), a recruitment function (Hooghe et al, 2004) and a socialization function (Cross and Young, 2008). All in all, party youth wings are entities that we need to know more of.

The current article aims to contribute to filling this gap by focusing on party youth wing membership. The ability of a party youth wing to attract members, and to do so independently from the mother party, is considered a highly relevant indicator of its success in linking young people to politics. Whenever party youth wings are suffering from membership decline, they are less effective in fulfilling their functions and thus become a less effective linkage strategy for political parties (Poguntke, 2002). Moreover, as participatory behaviour seems to take shape early in life (e.g. Hooghe and Stolle, 2002; Flanagan, 2009), it can be argued that, "if young people abandon youth organizations of political parties now, it will become more likely that, in future decades too, political parties will find it increasingly difficult to attract new members” (Hooghe et al, 2004, 195). Whenever party youth wing membership is in decline, this can thus be seen as yet another signal that the link between political parties and society at large is weakening.

In some countries, concerns are expressed on a declining membership base of youth wings, such as in Belgium (Hooghe et al, 2004, 199), Germany (Offe and Fuchs, 2002, 216) and Sweden (Rothstein, 2002, 294). However, the underlying data is either incomplete, outdated, or not displayed. Moreover, it is unclear whether differences between party youth wings exist, and if so, how these differences can be explained. This article tries to answer the question to what extent party youth wings succeed in attracting members and how variations in party youth wing membership levels can be explained. Organization-based explanations are developed and tested on a unique dataset that contains data for nine party youth wings and the corresponding mother parties in the Netherlands over a period from 2001 to 2016. The results show that, while the total party youth wing membership in the Netherlands is on the rise, large variations among party youth wings and their mother parties exist. The article attempts to explain these differences in party youth wing 
membership by looking at the role of various party youth wing- and party-related characteristics. By focusing on this underdeveloped field in research on party politics, the article not only provides us with better insight into the value of party youth wings within Western democracies, but also contributes to debates on both political youth participation and the relationship between political parties and young society.

\section{Explaining party youth wing membership levels}

In the party literature, most studies of political party membership focus on the aggregate countrylevel (e.g. Van Biezen et al, 2012; Whiteley, 2011). The use of aggregated data helps in establishing the bigger picture, providing an important indicator of "the extent to which parties might be regarded as retaining a hold within the wider society” (Mair and Biezen, 2001, 8). Looking at party youth wing membership from such a broad perspective, it can be expected that party youth wings experience difficult times when it comes to attracting members. Namely, in many established democracies there is empirical evidence for a disproportionally lower partisan engagement among younger generations (e.g. Sloam, 2013; Norris, 2002). Young people are less likely to vote than older people (Blais et al, 2004; Fieldhouse et al, 2007; Quintelier, 2007) and are underrepresented among party members (Scarrow and Gezgor, 2010; Cross and Young, 2004). As party youth wings function close to political parties in the sphere of traditional politics, it is expected that young people also distance themselves from these organizations. More specifically, political disengagement is particularly found among the young (Whiteley, 2007), so that party youth wings might suffer from membership decline to a greater extent than political parties. Indeed, Mair and Biezen (1999) conclude on the basis of the Katz and Mair (1992) party organization dataset, that half of the party youth wings in long-established democracies are losing members more rapidly than their mother party, although they also emphasize that the data should not be considered fully reliable. Following this, it can thus be expected on the aggregate level that, 
H1 Party youth wing membership is declining even faster than political party membership.

However, aggregated data can conceal variations in membership between organizations. In the case of party membership, studies that disaggregated figures at the party level have shown that several parties counter the common country-level trend of decline (Kölln, 2014; van Haute et al, 2017). This implies that party membership is not only affected by external factors; that certain organizational characteristics might work as facilitating factors for an individual's political membership. Party-level explanations thus need to be taken into account when studying membership levels and development.

The same can be applied to party youth wings. Party youth wings can be perceived as both actors in themselves and as closely connected to a political party. Certain characteristics of the party youth wing and the corresponding mother party might have an influence on the willingness of young people to join such an organization. Moreover, although it seems self-evident that mother party characteristics affect party youth wing membership, a certain degree of organizational autonomy implies that party youth wings need not follow the same membership trend as their mother party. The question is how the membership base of individual party youth wings develops compared to that of the mother party and to what extent youth wing membership is affected by both party youth wing- and party-level factors. In what follows, both sets of factors will be explained and hypotheses will be formulated.

Two party youth wing characteristics will be explored in the current study: ideology and party youth wing age. First, the ideological family a party youth wing belongs to might lead to variation between party youth wings in membership levels. Political perceptions and preferences diverge across different life-cycle stages and different age cohorts (Joshi, 2013). Some argue, for instance, that young people are more liberal; that political conservatism increases with age 
(Sanders, 1993; Wattenberg, 2007). Liberal party youth wings might thus be more successful in attracting members. Others argue that a shift in cultural values is taking place over generations, that young people are increasingly becoming prone to life-style and non-materialistic values (Kimberlee, 2002). Inglehart (2008) is well-known for his work on changing values, showing that younger generations embrace post-materialist values to a greater extent than older generations. In a political sense they might thus be more interested in quality of life issues instead of class-based issues. Although Kölln (2014) has not found an effect of the party family on membership levels and trends of political parties, she does show that the ecological party family is the only group that experiences membership increases. In addition to the liberal party youth wings, the party youth wings of parties that adhere to post-materialism are thus also expected to be more popular among the young. These studies also suggest that party youth wings of ideological families such as Christian, left socialist and social democratic parties, are becoming less and less attractive to young people. In short, it is expected that party youth wings of the post-materialist and social-liberal party families show higher membership levels than other party youth wings.

Complementary to party family, the age of the party youth wing may be associated to membership levels. In the literature, political organizations are often considered to go through several stages in their development (Katz and Mair, 1995; Biezen, 2005) and to institutionalize the more they gain experience (Panebianco, 1988; Randall and Svåsand, 2002). Kölln (2014) has shown that the age of a political party, as a proxy for institutionalization, affects membership levels. When parties are more consolidated, they are more likely to experience declining memberships. It can be argued that, just as political parties, party youth wings exert great recruitment efforts in the first phase of its organizational existence. However, while members might become somewhat less relevant for parties once they have stabilized, for party youth wings having members is their most important factor for survival. Over time, party youth wings gain experience and expertise, and might thus be able to recruit members more easily. It is thus expected that the party youth wing's 
age is positively related to the membership size of a party youth wing.

In summary, the following hypotheses focus on the set of factors that concern the influence of party youth wing characteristics:

H2a Party youth wings that adhere to post-materialist and liberal values show higher membership levels than other party youth wings.

$\boldsymbol{H} \mathbf{2 b}$ The party youth wing's age is positively related to its membership size.

A second set of factors focuses on mother party characteristics. The political party a youth wing is affiliated to, is part of the same party family and has more or less the same age. However, the mother party can possess other characteristics that might influence party youth wing membership, causing variation between party youth wings. Here, the focus lays on mother party performance, which might reflect on the popularity of party youth wings and thus their ability to attract members. For instance, when a certain party is successful in attracting a large number of members, it can be expected that the corresponding party youth wing also enjoys high membership figures, assuming that the same mechanisms are at play. Other indicators of mother party performance are electoral success and governmental participation. In the party literature, multiple studies focus on the positive relationship between a party's electoral success and its membership levels. For instance, Paulis et al (2017) found that party membership levels increase or decrease analogous to the extent of electoral success. Similarly, Whiteley and Seyd (1998) argue on the basis of levels of party activism in Britain, that electoral success positively influences support for policy goals and feelings of political and group efficacy, thus boosting the willingness to become an active party member. Moreover, for those people that are interested in building a political career, a winning party increases the chance of actually realizing this interest (Whiteley and Seyd, 1998). This is especially the case when parties manage to participate in government. Successful parties, in 
terms of electoral success and governmental participation, are thus more likely to have a large membership base. The same can be expected for the corresponding party youth wings. Adolescents in particular find themselves in a turbulent life stage in which they crystallize their political ideals, social networks and professional future (Arnett, 2000). As their political preferences are not stabilized yet, they have not developed certain habits and are thus more susceptible for trends than their older counterparts. All in all, it might be expected that young people are more attracted to party youth wings of political parties that are successful, than to party youth wings of political parties that are unsuccessful.

H3a The membership levels of the mother party are positively related to the membership levels of the party youth wing.

$\boldsymbol{H} 3 \boldsymbol{b}$ The electoral performance of the mother party is positively related to the membership levels of the party youth wing.

H3C Governmental participation of the mother party has a positive influence on the party youth wing membership levels.

Finally, election years are taken into account in the current study. Although this is not an organization-level factor, election years might boost membership levels regardless of the electoral outcome. Right before elections, membership levels can show a sudden growth, as people might join for the "electoral battle” (Carty et al, 2000, 158). Also, during elections, political parties and the party youth wings receive more media attention and have volunteers and campaigners on the streets, thus making them more salient for potential members. Even though young people are less likely to participate in elections (Blais et al, 2004; Fieldhouse et al, 2007; Quintelier, 2007), elections years might have some effect on party youth wing membership levels. The following hypothesis is proposed: 
H4 In election years, party youth wing membership levels are higher.

\section{Data and methods}

The hypotheses are tested using annual membership data on individual party youth wings and the corresponding political parties in the Netherlands between 2001 and 2016 in multilevel and timeseries analyses.

\section{The Dutch case}

The Dutch party system can be characterized as an open, multi-dimensional and multi-party system since the second half of the nineteenth century. This country offers an interesting context for the current study for two reasons. First, it has a long tradition with a variety of party youth wings. Already in 1888 the first youth wing was established: the Sociaal Democratische Jongeliedenbond (in English: the Social Democratic Youth League), which was closely affiliated to the first socialist party (Harmsen, 1971). Many other political parties followed. Since then, around ten alternating party youth wings have continued to exist in the Netherlands. Second, structural public funding for Dutch party youth wings exists since 1976 (Koole, 2011), which has fostered organizational development and data administration and availability. Some other countries offer public funding to party youth wing, such as Austria, Cyprus and Germany (van Klingeren et al, 2015). Although a single-country design knows its limitations such as restricted generalizability, it makes the Netherlands a good starting point for learning more about an understudied political phenomenon and allows for studying organizational differences.

Table 1 shows that nine out of eleven political parties that were represented in the Dutch House of Representatives in February $2017^{1}$ have their own party youth wing. Both older and newer political parties in the Netherlands are affiliated with a party youth wing. Whenever political parties 
do not have a party youth wing, this logically results from their party organizations. For instance, the Party for the Elderly (50PLUS) has no interest in a young constituency, and The Freedom Party (PVV), usually characterized as the Dutch radical right-wing populist party, has no members at all.

\section{* Table 1 around here *}

\section{Dependent variable: Membership data}

The membership data originate from the Ministry of the Interior and Kingdom Relations. The law that regulates the state funding of parties prescribes that the amount of youth wing funding depends on 1) the number of seats in parliament and 2) the amount of members of the youth wing (Political parties funding Act; Wet financiering politieke partijen, Wfpp, art.8.c). As the latter condition was only added to the Act in the year 2000, youth wing membership figures are available from 2001. Membership data are reported by the Ministry on the first of January of the concerning year. The Act demands that an accountant is appointed to report on the faithfulness and legality of the provided membership information by the parties (Wfpp, art. 25.2). For this reason, and because party youth wings appeared not very conscientious in data archiving, the data of the Ministry was chosen over self-reported membership figures.

Two characteristics of the data have to be taken into account when interpreting the results. First, the Act prescribes that each party youth wing has to count over a 100 members, who are not younger than 14 and not older than 27 years old, and who pay a membership-fee of at least five euros per year (Wfpp, art. 3). This membership definition of the Act differs somewhat from the definition that is applied by party youth wings themselves, so that self-reported membership data would present a slightly different story. For instance, most party youth wings accept members that are younger or older than the required age. The CDJA, the youth wing of the Christian Democratic Appeal (CDA), has not adopted a minimum age for membership. The SGPj, the youth wing of the 
Political Reformed Party (SGP), requires members to be at least eleven years old. The maximum age for members fluctuates between 28 and 30 across party youth wings. The presented membership data in this article might thus be somewhat underrepresented. Second, the so-called duo-members, young persons who are a member of both the party and the party youth wing, could not be identified. All Dutch party youth wings offer the duo-membership form, offering a financial advantage compared to a mere membership of the party, except for ROOD (the youth wing of the Socialist Party) and the SGPj. In case of a duo-membership option, there is thus a certain overlap between the membership figures of the political parties and corresponding party youth wings.

\section{Independent variables}

To test the first set of hypotheses on party youth wing characteristics, information is needed on the party youth wing's ideology and age. The Green-Alternative-Libertarian (GAL) to TraditionalAuthoritarian-Nationalist (TAN) dimension from the Chapel Hill Expert Survey (CHES) is used for identifying the party family (Polk et al, 2017; Hooghe et al, 2002). The GAL-TAN scale spans from post-materialist or social-liberal values $(\mathrm{GAL}=1)$ to social conservatism (TAN=10), which is thus very suitable for testing hypothesis 2a. The variable party youth wing age was computed through the year of foundation, as reported in the organizations' statutes (Table 1).

To test the second set of hypotheses on the influence of mother party characteristics, information is needed on the mother party's membership figures, electoral success, and governmental participation. Just as the party youth wing membership data, party membership data was received from the Ministry of the Interior and Kingdom Relations based on the Political parties funding Act. Generally, these might be somewhat lower than self-reported membership figures, as parties may use a broader definition of membership than as the funding Act prescribes (Wfpp, Art. 7.1). Information on electoral success, operationalized in the number of parliamentary seats, was derived from the Election Results Database of the Dutch electoral council (Kiesraad, 2018). 
Information on the parliamentary status, being either participation in opposition (0) or in government (1), was retrieved from the website parlement.com.

Election years were identified via the Election Results Database of the Dutch electoral council (Kiesraad, 2018).

\section{Data-analysis}

Characteristics are collected for each party youth wing and each year between 2001 and 2016. Two kinds of factors are thus included in the dataset: time-variant factors, such as age, membership figures and party performance, and time-invariant or cross-sectional factors, such as party family. As observations are nested in years for each party youth wing, the dataset has an hierarchical structure. The dataset has balanced data for most party youth wings, only ROOD and PINK! have missing data for the years prior to their founding year.

The most suitable method for analysing a dataset with these characteristics is multilevel modelling, as it acknowledges the clustered error structure by nesting membership observations within party youth wings. In a multi-level model with time series, one distinguishes between level-1 variables, which are time-variant, and level-2 variables, which are time-invariant between-subjects factors. It is important to recognize that time series are often non-stationary, meaning that observations are not independent and that correlations between observations increases when their distance in the time unit decreases. A plot of the autocorrelation function (ACF) indeed indicated the presence of residual serial correlation. In order to correct for this, a first-order autoregressive term, AR(1), was added to the multilevel model at level-1. Party youth wing id was included in the model as a random intercept in order to account for variation between youth wings. The variable time was incorporated into the random part of the model, so that slopes are allowed to vary in their growth or decline over time. In other words, each party youth wing was permitted to have a unique trajectory over time. All other variables were included as fixed effects. The variables number of 
parliamentary seats, governmental participation and election years were lagged by one year, making sure that the cause preceded the consequence. In addition, the variables party membership and parliamentary seats were log-transformed in order to eliminate skewed distributions. For instance, the majority of parties in the dataset has a smaller number of seats, and there are interdependencies of seat shares between the parties that have to be accounted for. Prior to the multilevel models, several time series analyses will be presented in which the trajectories of individual and grouped party youth wings are investigated using sequence charts of absolute numbers.

\section{Results}

Dutch party youth wing membership in the 21st century

In order to test the first hypothesis, several descriptive time series will be reported. Figure 1 presents the longitudinal trend of the aggregate membership of party youth wings and political parties in absolute numbers between 2001 and 2016. Surprisingly, the total level of youth wing membership has almost doubled in the last sixteen years, showing a total increase of 74 per cent. At the same time, the Netherlands is not a unique case in terms of total party membership figures, as these have been mainly in decline for decades (Voerman, 2016). The total party membership as a proportion of the electorate, the $\mathrm{M} / \mathrm{E}$ ratio, is found to be stabilized over the last decade, but quite low (see for example Den Ridder et al, 2015: they report 2.5\% in 2012).

Although absolute numbers are informative, it remains unclear whether the total number of party youth wing members can be generally classified as high. This can be assessed by expressing party youth wing membership as a percentage of young society. In order to calculate this ratio, the total number of young citizens aged 14-27 is extracted out of the database Statline of Statistics Netherlands. In 2001, the percentage of young people being a member of one of the party youth wings included in this study was 0.34 per cent. In 2016, this ratio was 0.55 per cent. Despite the 
increase, it can still be considered as an extremely low ratio. It is much lower than the M/E ratio of Dutch political parties, confirming that young people are less inclined to join a political party or a party-sub organization than their older counterparts. Nevertheless, based on this aggregated picture, the first hypothesis should be rejected: Party youth wing membership is not declining faster than political party membership. The total party youth wing membership trend diverges from that of political parties.

\section{* Figure 1 around here *}

A disaggregation of the two trajectories on the party-level indicates great variation between party youth wings and between party youth wings and their mother parties. Figure 2 shows that several parties and party youth wings qualify the common trends as identified in Figure 1, while others counter the common trends. The total increasing membership base of Dutch party youth wings is predominantly a reflection of rises in membership numbers of the Young Democrats (JD) of D66 (Democrats 66), the Youth Organisation Freedom and Democracy (JOVD) of the VVD (Liberal Party) and the Young Socialists (JS) of the PvdA (Labour Party). The SGPj of the Political Reformed Party and PpF, the youth wing of the Christian Union (CU), both suffer from decreases in their membership base. Nevertheless, the SGPj is still one of the largest party youth wings in the Netherlands, which is possibly explained by the remaining and easily accessible structures of the pillarization, such as reformed schools, events for reformed youth and family traditions in partisanship. The remaining party youth wings have a relatively stable, but small, membership base. All in all, some membership bases are increasing and others are decreasing, showing the need for an analysis of youth wing- and party-level factors that might explain the varying levels of membership.

\footnotetext{
* Figure 2 around here *
} 
Figure 2 also illustrates that trends in levels of party youth wing membership can deviate from membership trends of the corresponding mother party. Correlations are reported as a measure of trend similarity, which show that the nature of the membership relationship diverges for some parties and converges for others. Interestingly, four cases yield negative correlations. Whereas youth wing membership is increasing, we see eroding membership levels of the CDA ( $r=-.54$, $P<.05)$, PvdA ( $r=-.75, P<.01)$, and VVD $(r=-.88, P<.01)$. For the SGP it is the other way around, as its youth wing is slightly losing members while the party is gaining members $(r=-.70, P<.01)$. The other four party youth wings show a positive relation with their mother party. In particular, strong positive correlations are observed between the membership trends of the JD and its mother party ( $r=.96, P<.01)$ and between the membership trends of the Green Left Youth Organisation (DWARS) and its mother party $(r=.88, P<.01)$.

Lastly, Table 2 shows the calculated ratio between youth wing membership and party membership per political party at three time periods, enabling for a comparison across political parties. This ratio is computed by dividing the number of party youth wing members by the number of members of the corresponding mother party. The mean level of youth wing membership in relation to the party membership has risen from 4.95 per cent in 2001 to 6.79 per cent in 2016. Five of the nine political parties show a positive trend. The ratio of the membership of the JD of D66 and the JOVD of the VVD has grown spectacularly. The ratio of PpF with regard to the Christian Union (CU) and of PINK! with regard to the Party for the Animals (PvdD) show the strongest decline.

\section{* Table 2 around here *}

These results show that the membership organizations of most Dutch party youth wings are not shrinking faster than the mother party’s memberships. The youth wing membership trends are not uniform and do not correspond unequivocally to the membership trends of the mother party. 
This requires a more thorough exploration of the possible factors that might explain the variation in membership levels between party youth wings.

\section{Explaining party youth wing membership levels}

This section explores the relationship between the independent variables and the membership levels of party youth wings. First, some descriptive bivariate analyses of party youth wing trajectories are presented, in addition to those that were presented in the previous section. In order to explore the role of ideology, party youth wings are categorized into either a GAL or a TAN category, based on their score on this scale (see Table 1). As the JOVD has a middle score on the scale, it is excluded here. Figure 3 shows the membership time series for the two categories. Over the last sixteen years, the two categories of party youth wings converge in terms of membership figures. Youth wings with post-materialist or social-liberal values enjoy increasing membership levels, while youth wings that adhere to social conservatism are slightly in decline.

\section{* Figure 3 around here *}

To explore the role that the age of the party youth wing plays in determining membership levels, membership time series are inspected for three groups: old, middle old and young party youth wings (Figure 4). The category 'old' party youth wings refers to the three party youth wings that are founded before 1960, the category 'middle old' refers to the three party youth wings that are founded in the 1980s and the 1990s, and the category 'young' refers to the three party youth wings that are established since the year 2000. Figure 4 shows that the group of old and middle old party youth wings on average yield higher membership levels than the group of young party youth wings, although the sudden increase in the middle old category is probably caused by the JD. The latter category of youth wings experiences more challenge in attracting a substantive number of members. 
It can be concluded from this figure that the longer established parties are better at maintaining these kinds of organizational structures than younger parties.

\section{* Figure 4 around here *}

To test the hypotheses that aim to explain membership levels of party youth wings, multilevel models are used. The results are presented in table 3. Turning to the first set of hypotheses that focused on party youth wing characteristics, hypothesis 2a proposed that party youth wings that adhere to post-materialist and liberal values show higher membership levels than other party youth wings, and hypothesis $2 \mathrm{~b}$ proposed that party youth wing age is positively related to membership size. These two party youth wing characteristics were added to Model 1. Both party family and party youth wing age are found not to significantly affect membership levels (H2a and $2 \mathrm{~b}$ rejected).

Model 2 adds the independent variables mother party membership and the number of parliamentary seats of the mother party, which improves the model fit. The results confirm that the membership levels of the mother party are related to party youth wing's membership levels $(P<.001)$. An increase in the membership base of the mother party is associated with higher youth wing membership levels (H3a confirmed). However, the results also show that party youth wing membership is not affected by the electoral performance of the mother party (H3b rejected). Also governmental participation and election years, controlled for in model 3, do not show any significant results (H3c and 4 rejected). The inclusion of these variables does not affect the party membership effect, as that variable remains significant. All in all, of the included organization-level factors, only the membership levels of the mother party are thus found to significantly explain the membership levels of Dutch party youth wing. 


\section{Conclusion and discussion}

This article studied the membership base of nine party youth wings in the Netherlands between 2001 and 2016 by exploring time series and testing organization-level factors in a multilevel model. It is shown that youth wing membership levels on the aggregate-level are on the rise, but also that the percentage of young people being a member of a party youth wing is still very low. Moreover, strong differences in membership levels and trends are found across party youth wings, and party youth wings and the corresponding mother parties do not necessarily follow the same trend. This emphasizes the need to study disaggregated figures and to include organization-level characteristics in an explanatory analysis of memberships.

Of the organization-level factors that were included in the current study, the membership size of the mother is found to be positively related to party youth wing membership levels. This suggests that party youth wing membership figures do not develop independently from those of the mother party. The effect can possibly be explained by an overlap in membership base, although this requires further research. Young people that sign up for a party youth wing, might choose to become a duo-member and therefore also become a party member, and vice versa. There are also indications that older youth wings as a category enjoy higher membership levels, pointing to the ability of longer established parties in the Netherlands to maintain these kind of organizational structures, although an increase in organizational age did not have a significant effect on youth wing membership levels. It has been previously put forward that newer parties are characterized by weak organizational linkages (Poguntke, 2002). Against expectation, party family belonging, mother party performance in terms of electoral success and governmental participation, and election years do not seem to play a role in determining party youth wing membership. The choice to become a youth wing member is not so much based on political trends, but seems to be consciously made. Although party organizations are generally found to be changing, creating and upholding an organizational tie with a party youth wing is both a popular and traditional linkage strategy of Dutch 
parties in order to connect to young people. Poguntke $(1998,144)$ has argued that political parties are encouraged to develop their own internal interest organizations when traditional social organizations are in decline. In this way, parties aim to create an organizational forum for potential interests. Considering the low percentage of young people that is actually a member of a party youth wing, one may wonder whether this strategy is effective. But although the outreach of party youth wings is questionable, they can still offer serious young members that form an important recruitment pool to parties. It has to be taken into account here that the earmarked subsidy for party youth wings might also steer Dutch political parties towards having a youth wing. A cross-national study could shed light on the effect of the public funding of party youth wing on their appearance and functioning.

Overall, the results of the current study indicate that party youth wing membership is a phenomenon that cannot be easily explained. It requires further research on both the party- and macro-level in order to comprehend underlying causes. In addition, a larger amount of party youth wing data should be included in future research in order to substantiate the current findings and to be able to adopt a more dynamic perspective, i.e. also explain trends. Nevertheless, it is remarkable that some Dutch party youth wings are experiencing increasing membership figures in a context in which young people are found to have a problematic relationship with conventional politics (e.g. Sloam, 2013; Norris, 2002; Blais et al, 2004; Scarrow and Gezgor, 2010). They can be viewed as important participatory vehicles in which young people are schooled to secure the future of traditional politics. Among them, we may find tomorrow's leaders of our democracy (Bruter and Harrison, 2009, 153). The participation of young people in the political system is important for the functioning of a democracy. Comparative research on political parties and memberships should therefore more often report on the role of party youth wing and the levels of youth membership. Hopefully, this article has given a first impetus. 


\section{Notes}

${ }^{1}$ Table 1 is based on the composition of the House of Representatives of before the elections in March 2017. After the elections, two new party youth wings were founded, which could not be included in the current study due to a lack of data. 


\section{References}

Arnett J.J. (2000) Emerging adulthood: A theory of development from the late teens through the twenties. American Psychologist 55: 469-480.

Biezen I., van. (2005) On the theory and practice of party formation and adaptation in new democracies. European Journal of Political Research 44: 147-174.

Biezen I., van, Mair P. and Poguntke T. (2012) Going, going,...Gone? The decline of party membership in contemporary europe. European Journal of Political Research 51: 24-56.

Blais A., Gidengil E., Nevitte N. and Nadeau R. (2004) Where does turnout decline come from? European Journal of Political Research 43: 221-236.

Bruter M. and Harrison S. (2009) Tomorrow's leaders?: Understanding the involvement of young party members in six european democracies. Comparative Political Studies 42: 1259-1290.

Carty K., Cross W. and Young L. (2000) Rebuilding canadian party politics. Vancouver: UBC Press.

Cross W. and Young L. (2004) The contours of political party membership in canada. Party Politics 10: 427-444.

Cross W. and Young L. (2008) Activism among young party members: The case of the canadian liberal party. Journal of Elections, Public Opinion \& Parties 18: 257-281.

Den Ridder J., Van Holsteyn J. and Koole R. (2015) Party membership in the netherlands. In: Van Haute E. and Gauja A. (eds) Party members and activists. London: Routledge.

Fieldhouse E., Tranmer M. and Russell A. (2007) Something about young people or something about elections? Electoral participation of young people in europe: Evidence from a multilevel analysis of the european social survey. European Journal of Political Research 46: 797-822.

Flanagan C. (2009) Young people's civic engagement and political development. In: Furlong A. (ed) International handbook of youth and young adulthood. London: Routledge. 
Harmsen G. (1971) Blauwe en rode jeugd : Ontstaan, ontwikkeling en teruggang van de nederlandse jeugdbeweging tussen 1853 en 1940. Nijmegen: Socialistische Uitgeverij Nijmegen.

van Haute E., Paulis E. and Sierens V. (2017) Assessing party membership figures: The mapp dataset. European Political Science: 1-12.

Hooghe L., Marks G. and Wilson C.J. (2002) Does left/right structure party positions on european integration? Comparative Political Studies 35: 965-989.

Hooghe M. and Stolle D. (2002) De invloed van jeugdparticipatie op sociaal kapitaal-indicatoren bij volwassenen. Ethiek \& Maatschappij 5: 3-32.

Hooghe M., Stolle D. and Stouthuysen P. (2004) Head start in politics - the recruitment function of youth organizations of political parties in belgium (flanders). Party Politics 10: 193-212.

Inglehart R. (2008) Changing values among western publics from 1970 to 2006. West European Politics 31: 130-146.

Joshi D.K. (2013) The representation of younger age cohorts in asian parliaments: Do electoral systems make a difference? Representation 49: 1-16.

Katz R.S. and Mair P. (1992) Party organizations. A data handbook. London: SAGE publications Ltd.

Katz R.S. and Mair P. (1995) Changing models of party organization and party democracy: The emergence of the cartel party. Party Politics 1: 5-28.

Kiesraad. (2018) Election results database. https://www.verkiezingsuitslagen.nl/.

Kimberlee R.H. (2002) Why don't british young people vote at general elections? Journal of Youth Studies 5: 85-98.

van Klingeren M., Orozco M., van Spanje J. and de Vreese C. (2015) Party financing and referendum campaigns in eu member states, Brussels: European Parliament, Policy Department Citizens' Rights and Constitutional Affairs. 
Kölln A.-K. (2014) Party membership in europe: Testing party-level explanations of decline. Party Politics 22: 465-477.

Koole R. (2011) Partijfinanciën in nederland: Ontwikkelingen en regelgeving. In: Andeweg R.B. and Thomassen J. (eds) Democratie doorgelicht. Het functioneren van de nederlandse democratie doorgelicht. Leiden: Leiden University Press, 221-237.

Mair P. and Biezen I., van. (1999) Trends in enrolment in political parties in european polities, with particular reference to youth enrolment. Youth and Democracy, International IDEA. Stockholm, 17-19 june.

Mair P. and Biezen I., van. (2001) Party membership in twenty european democracies, 1980-2000. Party Politics 7: 5-21.

Norris P. (2002) Democratic phoenix: Reinventing political activism. Cambridge: Cambridge University Press.

Offe C. and Fuchs S. (2002) A decline of social capital? The german case. In: Robert D.P. (ed) Democracies in flux. The evolution of social capital in contemporary society. New York: Oxford University Press.

Panebianco A. (1988) Institutionalization. Political parties: Organization and power. Cambridge: Cambridge University Press.

Paulis E., Sierens V. and Van Haute E. (2017) Jumping on the bandwagon? Explaining fluctuations in party membership levels. Conference of the Political Studies Association. Glasgow.

Poguntke T. (1998) Party organisations. In: Deth J.W.v. (ed) Equivalence in comparative politics. London: Routledge.

Poguntke T. (2002) Party organizational linkage: Parties without firm social roots? In: Luther K.R. and Müller-Rommel F. (eds) Political parties in the new europe. Political and analytical challenges. Oxford: Oxford University Press. 
Poguntke T. (2006) Political parties and other organizations. In: Katz R.S. and Crotty W. (eds) Handbook of party politics. London: Sage.

Polk J., Rovny J., Bakker R., Edwards E. et al. (2017) Explaining the salience of anti-elitism and reducing political corruption for political parties in europe with the 2014 chapel hill expert survey data. Research \& Politics. SAGE Publications Ltd, 2053168016686915.

Quintelier E. (2007) Differences in political participation between young and old people. Contemporary Politics 13: 165-180.

Randall V. and Svåsand L. (2002) Party institutionalization in new democracies. Party Politics 8: 529.

Rothstein B. (2002) Sweden: Social capital in the social democratic state. In: Robert D.P. (ed) Democracies in flux. The evolution of social capital in contemporary society. New York: Oxford University Press.

Sanders D. (1993) Why the conservatives won - again. In: Sanders D., King A., Crewe I., Denver D. et al (eds) Britain at the polls 1992. Chatham, NJ: Chatham House.

Scarrow S.E. and Gezgor B. (2010) Declining memberships, changing members? European political party members in a new era. Party Politics 16: 823-843.

Sloam J. (2013) 'Voice and equality’: Young people’s politics in the european union. West European Politics 36: 836-858.

United Nations Development Programme. (2013) Enhancing youth political participation throughout the electoral cycle. A good practice guide, New York: United Nations Development Programme.

Voerman G. (2016) Gezamenlijk ledental nederlandse politieke partijen naar dieptepunt. Documentatiecentrum Nederlandse Politieke Partijen. Groningen.

Wattenberg M.P. (2007) Is voting for young people? New York: Pearson Longman. 
Whiteley P.F. (2007) Are groups replacing parties? A multi-level analysis of party and group membership in the european democracies. Britain After Blair. University of Chicago.

Whiteley P.F. (2011) Is the party over? The decline of party activism and membership across the democratic world. Party Politics 17: 21-44.

Whiteley P.F. and Seyd P. (1998) The dynamics of party activism in britain: A spiral of demobilization? British Journal of Political Science 28: 113-137. 


\section{Tables}

Table 1: Dutch party youth wings of political parties in parliament in February 2017.

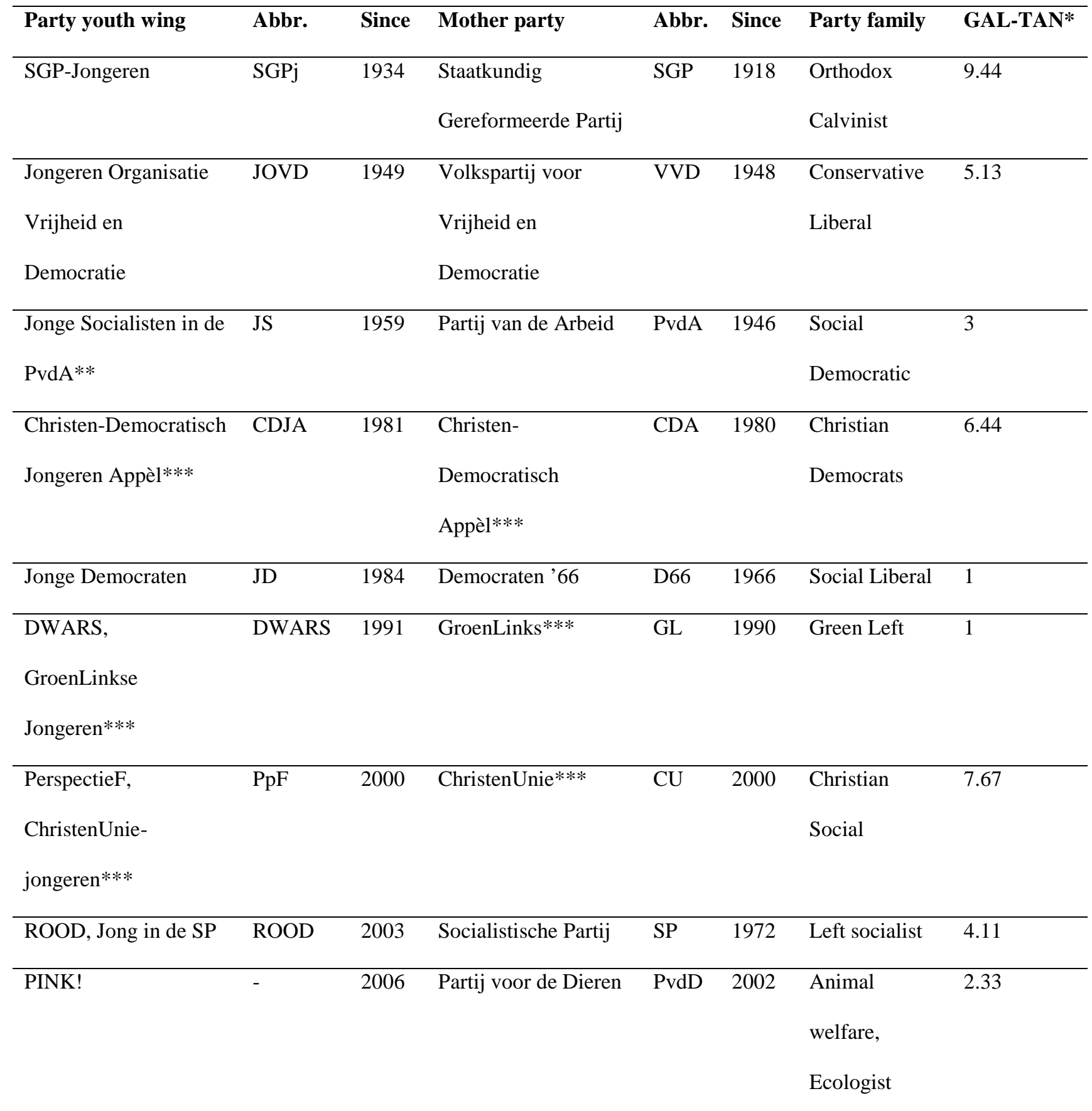

Notes. * Score on the Green-Alternative-Libertarian (GAL) to Traditional-Authoritarian-Nationalist (TAN) dimension: 11-point scale from 0 (libertarian/postmaterialist) to 10 (traditional/authoritarian). ${ }^{* *}$ The current name of the JS was adopted in 1977. ***Arisen from a merger. 
Table 2: Ratio between membership of party youth wings (PYW) and party membership*.

\begin{tabular}{lllll}
\hline Party & \% PYW members (t1) & \% PYW members (t2) & \% PYW members (t3) & Trend \\
\hline CDA & $0.93 \%$ & $1.54 \%$ & $1.79 \%$ & up \\
CU & $9.94 \%$ & $5.67 \%$ & $3.74 \%$ & down \\
D66 & $2.36 \%$ & $10.59 \%$ & $17.83 \%$ & up \\
GL & $2.71 \%$ & $3.53 \%$ & $4.59 \%$ & up \\
PvdA & $1.19 \%$ & $2.19 \%$ & $3.78 \%$ & up \\
PvdD & n/a & $9.55 \%$ & $6.50 \%$ & down \\
SGP & $15.82 \%$ & $15.66 \%$ & $11.55 \%$ & down \\
SP & n/a & $4.67 \%$ & $3.17 \%$ & down \\
VVD & $1.70 \%$ & $3.51 \%$ & $8.16 \%$ & up \\
Mean (n) & $4.95 \%(7)$ & $6.32 \%(9)$ & $6.79 \%(9)$ & up \\
\hline *1 = 2001, t2 $=2008, \mathrm{t} 3=2016$. & & &
\end{tabular}


Table 3: Multilevel models with party youth wing membership as dependent variable.

\begin{tabular}{|c|c|c|c|}
\hline & Model 1 & Model 2 & Model 3 \\
\hline (Intercept) & $\begin{array}{l}145.50 \\
(524.45)\end{array}$ & $\begin{array}{l}-14778.34^{* * *} \\
(3240.39)\end{array}$ & $\begin{array}{l}-16124.50 * * * \\
(3364.60)\end{array}$ \\
\hline Party youth wing age & $\begin{array}{l}14.41 \\
(11.84)\end{array}$ & $\begin{array}{l}27.03 \\
(18.05)\end{array}$ & $\begin{array}{l}28.01 \\
(18.39)\end{array}$ \\
\hline Party family (GAL-TAN) & $\begin{array}{l}189.60 \\
(103.16)\end{array}$ & $\begin{array}{l}-167.60 \\
(176.77)\end{array}$ & $\begin{array}{l}-191.97 \\
(181.12)\end{array}$ \\
\hline Mother party membership (in log) & & $\begin{array}{l}1633.63^{* * *} \\
(317.62)\end{array}$ & $\begin{array}{l}1773.77^{* * *} \\
(329.28)\end{array}$ \\
\hline Parliamentary seats (in log and lag) & & $\begin{array}{l}-154.79 \\
(97.10)\end{array}$ & $\begin{array}{l}-148.40 \\
(102.80)\end{array}$ \\
\hline Participation in opp. or gvt. (in lag) & & & $\begin{array}{l}-23.14 \\
(92.61)\end{array}$ \\
\hline Election year (in lag) & & & $\begin{array}{l}-46.32 \\
(38.68) \\
\end{array}$ \\
\hline Variance Level-1 (within-unit) & 399318.68 & 149435.12 & 141868.31 \\
\hline Variance Level-2 (intercept) & 552885.79 & 3967540.33 & 4412444.49 \\
\hline Variance Level-2 (slope) & 9251.30 & 9306.98 & 9448.16 \\
\hline$\overline{\mathrm{AIC}}$ & 1811.43 & 1771.75 & 1754.07 \\
\hline BIC & 1833.93 & 1799.71 & 1787.42 \\
\hline Log Likelihood & -897.72 & -875.88 & -865.04 \\
\hline Observations & 126 & 126 & 126 \\
\hline Groups & 9 & 9 & 9 \\
\hline
\end{tabular}

Note: Standard errors in parentheses. All models control for first-order autocorrelation (AR(1)).

AIC: Akaike information criterion; BIC: Bayesian information criterion. ${ }^{* * *} P<0.001$.

Figures

Figure 1: Total members of Dutch party youth wings and political parties 2001-2016. 


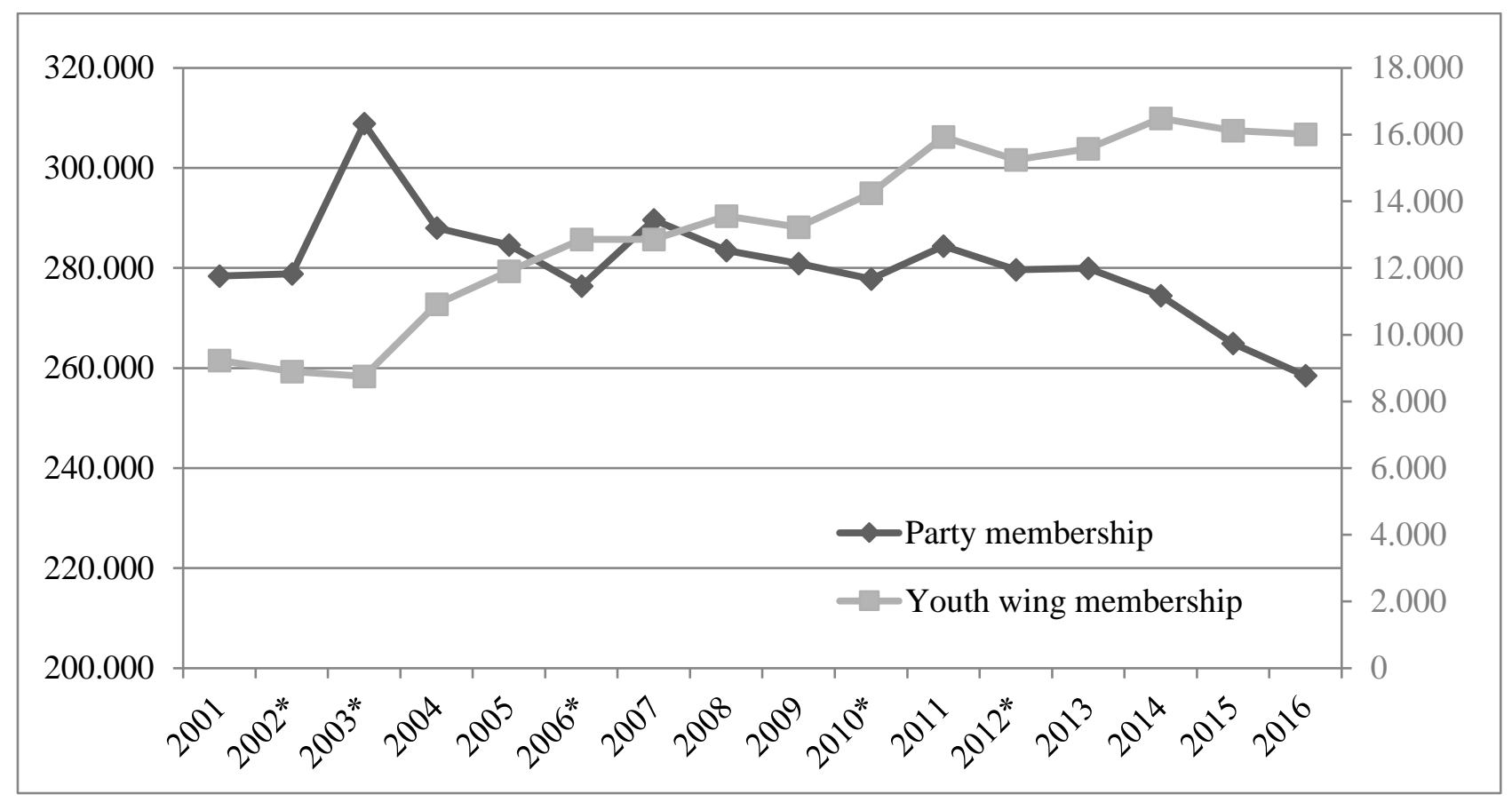

*Election year. 
Figure 2: Trends in party youth wing and mother party membership 2001-2016.

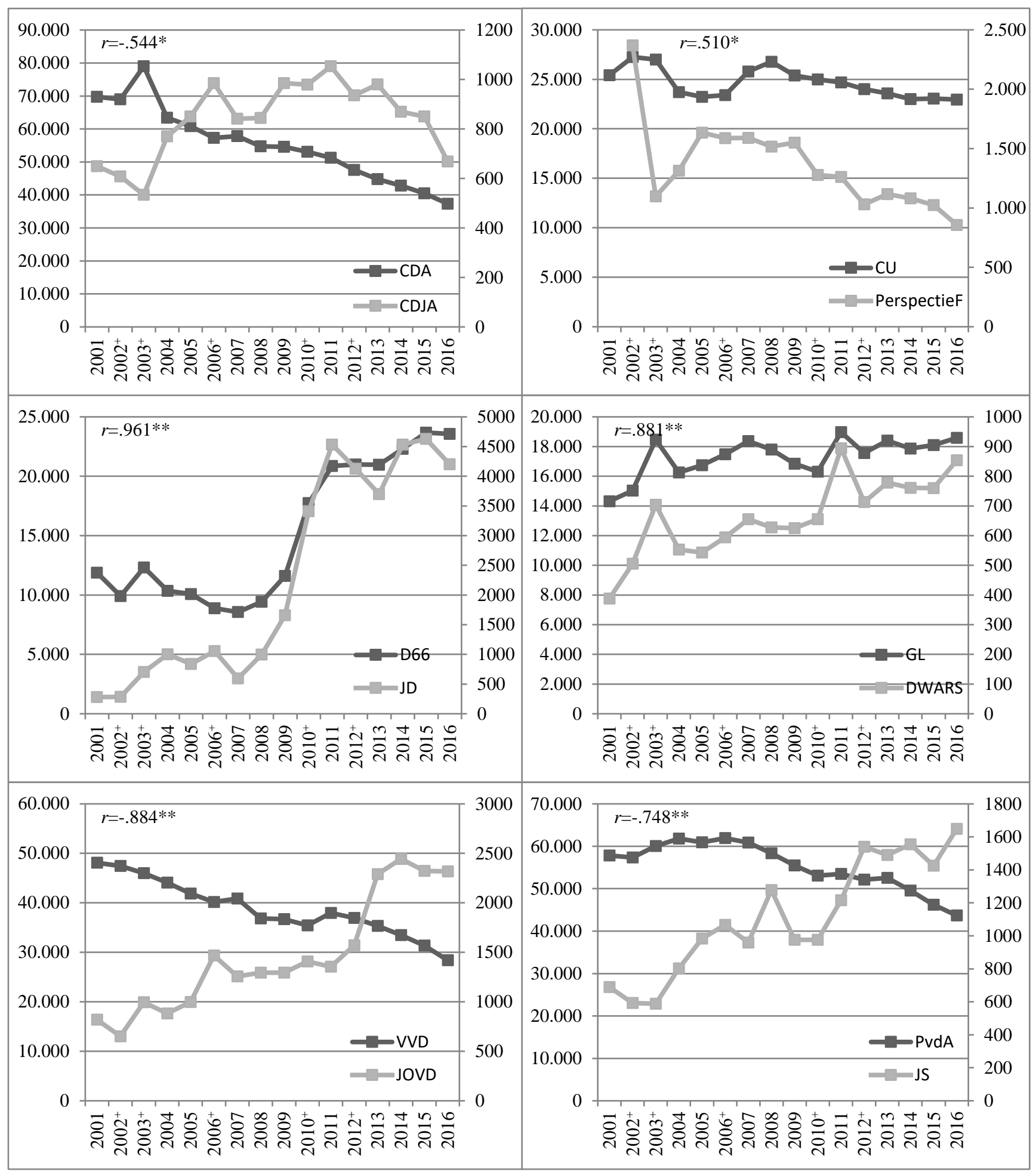


Figure 2 (continued): Trends in party youth wing and mother party membership 2001-2016.

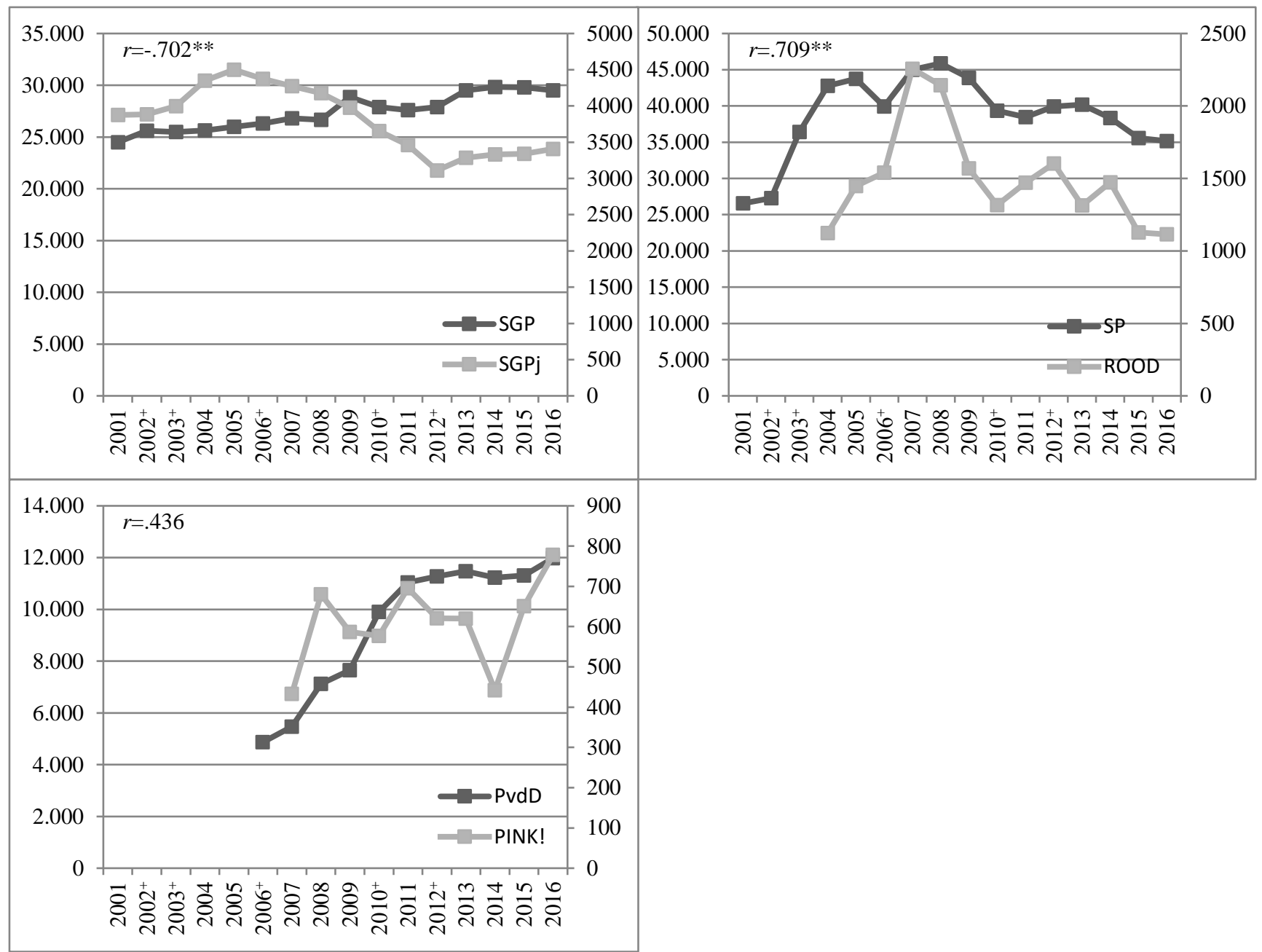

${ }^{+}$Election year; $* P<0.05 ; * * P<0.01$.

Note: Please note that the scales on the y-axes differ. 
Figure 3: Dutch party youth wing membership per ideological category.

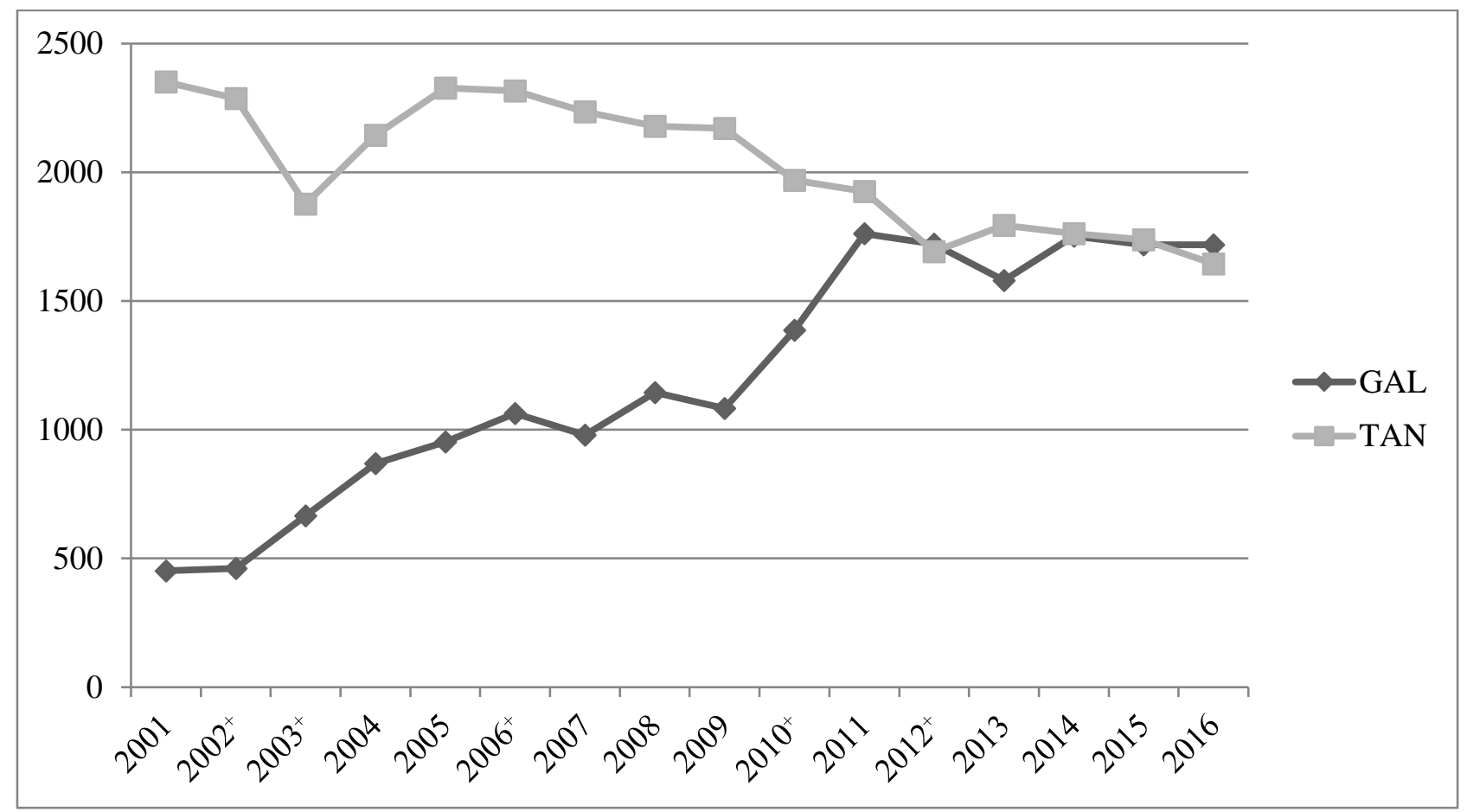

${ }^{+}$Election year.

Note: The JOVD is excluded because of their middle score on the GAL-TAN scale. 
33

Figure 4: Dutch party youth wing membership per age category.

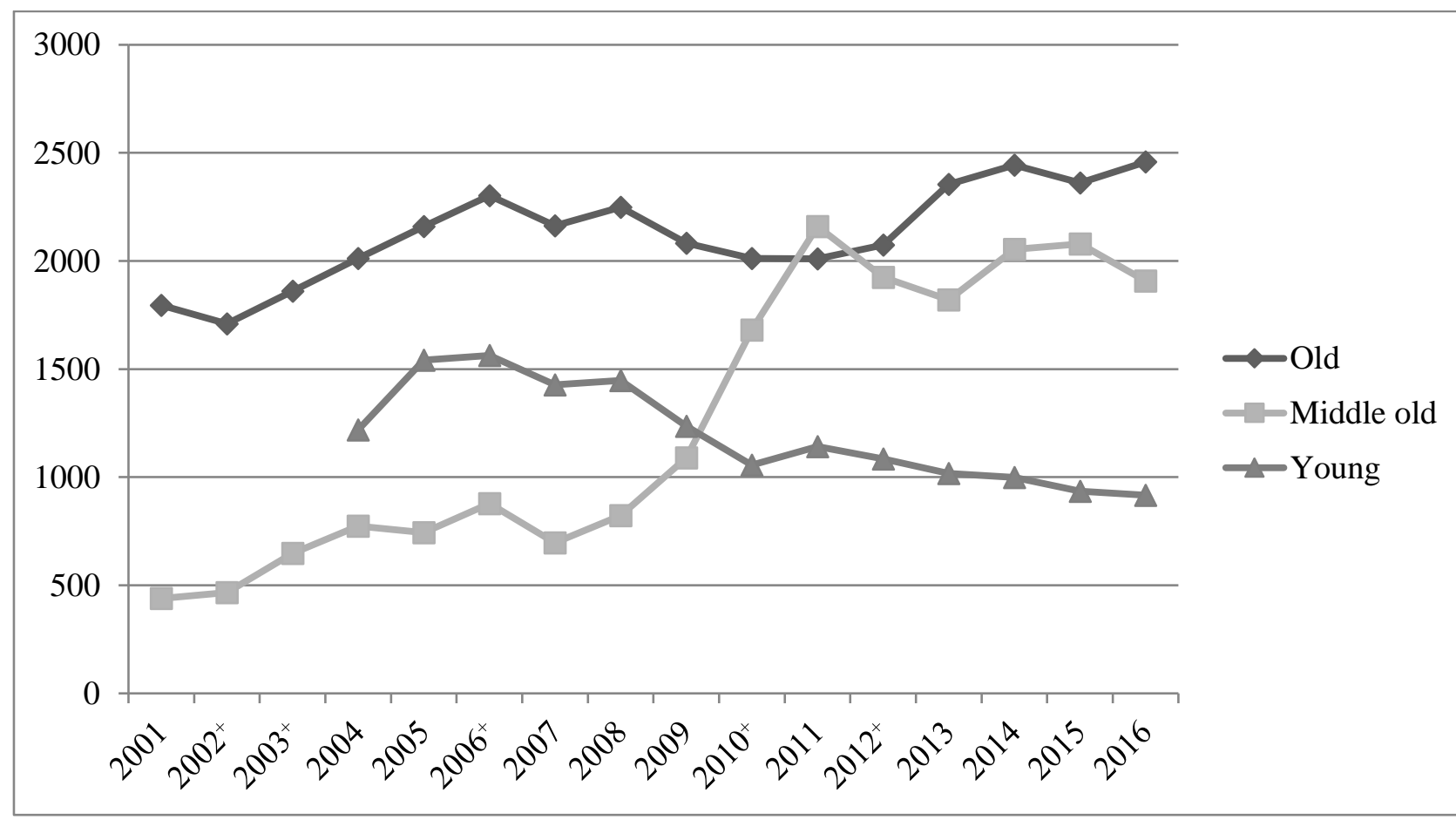

${ }^{+}$Election year.

Note: The category 'young' starts in 2003 because prior to that year only the Pp existed. 